\title{
REVIEW
}

\section{Managing symptoms in hypothyroid patients on adequate levothyroxine: a narrative review}

\author{
Salman Razvi ${ }^{1}$, Sanaa Mrabeti² and Markus Luster ${ }^{3}$ \\ ${ }^{1}$ Translational and Clinical Research Institute, University of Newcastle, Newcastle-upon-Tyne, UK \\ ${ }^{2}$ Medical Affairs EMEA, Merck Serono Middle East FZ-LLC, Dubai, United Arab Emirates \\ ${ }^{3}$ Department of Nuclear Medicine, University Hospital Marburg, Marburg, Germany
}

Correspondence should be addressed to S Razvi: salman.razvi@ncl.ac.uk

\begin{abstract}
The current standard of care for hypothyroidism is levothyroxine (LT4) monotherapy to reduce levels of thyrotropin (thyroid-stimulating hormone, TSH) within its reference range and amelioration of any symptoms. A substantial minority continues to report hypothyroid-like symptoms despite optimized TSH, however. These symptoms are not specific to thyroid dysfunction and are frequent among the euthyroid population, creating a therapeutic dilemma for the treating clinician as well as the patient. We present a concise, narrative review of the clinical research and evidence-based guidance on the management of this challenging population. The clinician may endeavor to ensure that the serum TSH is within the target range. However, the symptomatic patient may turn to alternative non-evidence-based therapies in the hope of obtaining relief. Accordingly, it is important for the clinician to check for conditions unrelated to the thyroid that could account for the ongoing symptoms such as other autoimmune conditions, anemia or mental health disorders. Systematic and thorough investigation of the potential causes of persistent symptoms while receiving LT4 therapy will resolve the problem for most patients. There may be some patients that may benefit from additional treatment with liothyronine (LT3), although it is unclear as yet as to which patient group may benefit the most from combined LT4 + LT3 therapy. In the future, personalized treatment with LT4 + LT3 may be of benefit for some patients with persistent symptoms of hypothyroidism such as those with polymorphisms in the deiodinase enzyme 2 (DIO2). For now, this remains a subject for research.
\end{abstract}

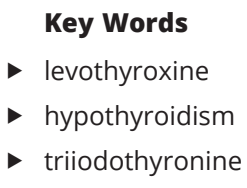

Endocrine Connections (2020) 9, R241-R250

\section{Introduction}

Current management guidelines for the management of hypothyroidism focus on the administration of levothyroxine (LT4), with doses titrated to bring thyroidstimulating hormone (thyrotropin, TSH) within a locallyderived reference range of 'normal' values $(1,2,3)$. Spontaneous hypothyroidism is a common condition, affecting approximately $1-2 \%$ of adults in iodinereplete areas of the world (4), although a much higher prevalence has been described in some countries, for example, about $10 \%$ in a study conducted in eight large cities in India (5). Many more people have subclinical hypothyroidism, with a prevalence estimated as $8 \%$ in women (10\% in women aged $>55$ years) and $3 \%$ of men (4). Current recommendations support the prescription of levothyroxine to some patients with subclinical hypothyroidism, particularly where TSH is $>10 \mathrm{mU} / \mathrm{L}$ and FT4 is within the normal range (2), and the use of levothyroxine for the management of subclinical hypothyroidism appears to have increased $(6,7)$.

Consequently, LT4 is given widely: this treatment is currently the most prescribed medication in the USA and the $3^{\text {rd }}$-most prescribed treatment in the UK 
(120 million prescriptions, and 19 million prescriptions each year, respectively) (8). For most patients, administration of levothyroxine is sufficient to resolve symptoms of hypothyroidism and maintain quality of life $(1,2,3)$. However, a minority of people with hypothyroidism continue to report symptoms reminiscent of hypothyroidism, even following treatment with LT4 at doses sufficient to normalize TSH, with consequent impairment of their quality of life (9).

We present a narrative review that explores the extent and pathophysiologic nature of this problem. We also provide suggestions for managing this challenging population of patients.

\section{Search methods}

This is a narrative review. We searched the PubMed database for clinical trial data from inception to 30 March 2020 using the following search string: ((TSH OR thyrotropin) AND (hypothyroid OR hypothyroidism) AND symptoms) OR (euthyroid (ti) AND symptoms (ti)).

These searches provided a total of 7868 hits. The searches were narrowed down using the PubMed filters of 'clinical trial', 'randomised clinical trial', 'practice guideline', 'observational study', and 'meta-analysis'. The titles and abstracts of the resulting 560 hits were examined manually to identify data of interest. Additional specific customized searches provided material on prevalence of hypothyroidism, and so on. In addition, authors' personal literature collections and references from articles identified in the search also provided source material.

Wefocused on publications relatingtocurrent, guidelinedriven care of hypothyroidism. Thus, the therapeutic use of combinations of LT4 with triiodothyronine (T3) is not addressed in detail, beyond a brief account of the current status of clinical trials in this area.

\section{Persistent ill health on optimied levothyroxine therapy}

\section{Scale of the problem}

A survey in the UK used questionnaires to measure psychological health and symptoms reminiscent of thyroid disorders in 597 LT4 recipients and 551 controls, from a population matched for age and gender, using the records of five primary care centers (10).
Psychological and, especially, thyroid-related well-being, were significantly poorer in LT4 users vs controls. Wellbeing was impaired broadly similarly in LT4 recipients who did, or did not, have an adequately controlled TSH level. The differences between thyroid patients and controls persisted after multivariate adjustment for age, gender, concurrent medication use and comorbidities. Another study found a correlation between quality of life and levels of FT4 and TSH (but not FT3) in patients with TSH controlled to within the normal range (11). These data suggest that persistence of symptoms, including those potentially related to thyroid dysfunction, may be a common problem. This situation has important implications for resource provision, as additional clinic visits to check and adjust LT4 doses were associated with increased direct and indirect costs to the healthcare system and to society (12).

\section{Non-specific nature of symptoms of hypothyroidism}

Symptoms reminiscent of hypothyroidism tend to be nonspecific and difficult to distinguish from other conditions or general sub-optimal health (Table 1) $(13,14,15,16)$. There is some degree of association between elevation of TSH and the presence of hypothyroid-like symptoms, particularly when multiple symptoms were present or symptoms had appeared or intensified within the previous year, but many symptoms existed with equal frequency in hypothyroid and euthyroid subjects (17). Also, people with overt or subclinical hypothyroidism in the Colorado Thyroid Disease Prevalence Study were more likely to have three or more of these symptoms than euthyroid subjects, and euthyroid subjects were more likely to be free of these symptoms (13). However, the absolute difference in the prevalence of these symptoms between the two groups was small, and receiver operating characteristics analysis demonstrated sensitivity for detecting hypothyroidism of only $28 \%$ or less. A study from a population-based cohort in Denmark also found that symptoms reminiscent of hypothyroidism alone were a poor predictor of the presence of overt hypothyroidism (18). Thus, being free of these symptoms does not reliably exclude the presence of hypothyroidism. Equally, the presence of symptoms that could potentially be attributable to hypothyroidism does not consistently predict hypothyroidism either. Thyroid dysfunction may promote psychological disturbances, as described previously (19).
This work is licensed under a Creative Commons Attribution-NonCommercial-NoDerivatives 4.0 elnternationab dicense ifica.com at 04/26/2023 10:50:34AM 
Table 1 Typical symptoms of hypothyroidism.

\begin{tabular}{l} 
Examples of medical conditions or treatments that produce \\
symptoms resembling hypothyroidism \\
\hline Chronic fatigue \\
GI diseases that affect LT4 absorption \\
Addison's disease \\
Anemia \\
Stress \\
Changes in weight \\
Pregnancy \\
Medications that interfere with LT4 absorption ${ }^{a}$
\end{tabular}

Typical symptoms resembling those of hypothyroidism

\begin{tabular}{ll}
\hline Constipation & Feeling too cold \\
Puffy eyes & Slow thinking \\
Hoarse/deep voice & Tired/lethargic \\
Muscle cramps & Weight gain \\
Hair loss or dry hair & Depression \\
Dry or scaly skin & Loss of libido \\
Muscle weakness & Menstrual abnormalities \\
Carpal tunnel syndrome & Poor memory
\end{tabular}

See text. Compiled from references $(13,14,15,16)$.

$\mathrm{Gl}$, gastrointestinal; LT4, levothyroxine.

\section{Possible explanations for continuing symptoms despite 'adequate' biochemical euthyroid status}

The normal thyroid gland produces both T4 and T3, yet LT4 monotherapy has been the mainstay of replacement since the 1970s due to ease of administration, good absorption via the gut and its long half-life, thus allowing for once daily dosing with a very stable serum profile $(1,2,3)$. In addition, $\mathrm{T} 4$ can be converted to $\mathrm{T} 3$ by the various tissues depending on local requirement consequently alleviating the need to add LT3 (20). Furthermore, the majority of circulating T3 comes from peripheral conversion of T4 to $\mathrm{T} 3$ and not secretion from the thyroid gland, suggesting only a small role for secreted T3 in maintaining thyroid hormone homeostasis (21). It is also clear that circulating T3 levels may be low in hypothyroid patients treated with LT4 monotherapy $(22,23,24,25)$. Experimental evidence suggests that LT4 monotherapy in hypothyroid rats fails to normalize T3 levels in all tissues (26).

Three types of deiodinases regulate the conversion of $\mathrm{T} 4$ to T3, and the inactivation of both hormones (27). The expression of these enzymes varies between individuals, and between different cells in the body, and it has been suggested that such variations 'fine tune' the actions of thyroid hormones in different physiological systems (28). For example, it has been suggested that individuals with polymorphism in the deiodinase 2 gene (Thr92Ala) may have subtle changes in deiodinase activity leading to clinically important differences in tissue thyroid hormone bioavailability (29). In addition, LT4 monotherapy reduces the expression of the type 2 deiodinase primarily responsible for converting $\mathrm{T} 4$ to $\mathrm{T} 3$ (30), which may in principle exacerbate the relative $\mathrm{T} 3$ deficiency in patients with hypothyroidism receiving LT4 therapy. Thus, it is argued that LT4 therapy may not be sufficient on its own to return hypothyroid tissues to normal thyroid hormone state although serum TSH levels may be within the euthyroid range.

A cross-sectional study identified 9981 people with TSH within the normal range in the US National Health and Examination Survey (NHANES) (23). Analysis of individuals stratified by those receiving LT4 vs non-users of LT4 showed that serum TSH levels were similar in both groups (2.13 and $2.15 \mathrm{mIU} / \mathrm{L}$, respectively). However, LT4 recipients, compared with the euthyroid controls, had significantly lower total, LDL- and HDL-cholesterol, higher BMI, higher total and free T4, lower total and free T3. Furthermore, the LT4-treated hypothyroid patients had higher BMI and more use of cardiovascular medications compared with euthyroid controls despite normal TSH levels. These data suggest the presence of measureable biochemical differences between populations with and without hypothyroidism, even when TSH is controlled adequately according to guidelines.

Accordingly, considerable research interest has focused on administration of combinations of T4 and T3 to a patient with symptoms of hypothyroidism that are apparently refractory to LT4 (31). An initial double-blind, randomized trial in patients with hypothyroidism demonstrated improvements in mood and neuropsychological function in patients for whom $\mathrm{T} 3$ was given in place of a proportion of their LT4 dose (32). Further evidence from randomized or observational studies has supported the possibility of significant differences in quality of life (QoL) scores or psychological scores in favor of the combination vs LT4 monotherapy $(33,34)$, but a benefit for the combination for improved quality of life or other outcomes is not supported by systematic reviews or meta-analyses conducted as recently as 2018 (35, 36, 37, 38, 39). Importantly, about half of the patients enrolled in double-blind trials preferred the combination to LT4 monotherapy, however (40). Data on the safety of treatment with regimens including T3 are lacking (39), although long-term observational data

This work is licensed under a Creative Commons Attribution-NonCommercial-NoDerivatives 4.0 elnternational License.ifica, com at $04 / 26 / 2023$ 10:50:34AM 
from one LT4+LT3-treated cohort did not raise safety concerns (41). Nevertheless, care must be taken to avoid overtreatment in this setting, especially as the serum halflives of LT4 (days) and T3 (hours) do not match well, and balancing the dosages of LT4 and T3 is challenging (39). Current guidelines (42) and expert opinion (39) support the conduct of a carefully monitored trial of LT4+LT3 replacement, by a physician experienced in the management of thyroid disorders, for a patient with hypothyroid-like symptoms despite optimized LT4 monotherapy, with dosages optimized according to the TSH level. However, the therapeutic administration of $\mathrm{T} 3$ remains a topic for research $(3,42)$. Physicians should be aware that LT3-LT4 combination therapy is promoted increasingly in the media, and patients may initiate or titrate therapy without involving their healthcare team (43).

Whether the overall results of these trials concealed subgroups that may have been more responsive to LT3+LT4 combination therapy is unknown. In addition, trials may not have focused on patients populations with persistent symptoms of hypothyroidism despite optimized TSH. A further possible explanation for this discrepancy in results may be the presence of the polymorphism of the gene encoding $\mathrm{DIO}_{2}$, described previously (44).
Carriers of this polymorphism have been shown to demonstrate a relative state of hypothyroidism within the brain (45), and have tended in some studies to respond more favorably in terms of improved QoL to T4 plus T3 combinations, compared with treatment with $\mathrm{T} 4$ alone $(46,47)$. Other studies have not demonstrated a significant influence of variation in the gene for this enzyme on T4 requirement in hypothyroid patients (48), or on patientreported outcomes on (or preference for) treatment with LT4+T3 combination therapy (49). Further research will be needed to confirm whether genetic variations in deiodinases, and indeed in other sites of cellular access or action of thyroid hormones (such as membrane transporters, nuclear receptors and other sites) may facilitate individualized treatment of hypothyroid patients in the future $(44,50,51,52)$.

\section{Managing patients with persistent symptoms despite optimied levothyroxine therapy}

Symptoms associated with hypothyroidism are often nonspecific in nature, and common within the euthyroid population, as described previously, and a systematic and careful approach is needed to evaluate any association
Patient with hypothyroidism presents with symptoms despite receiving LT4

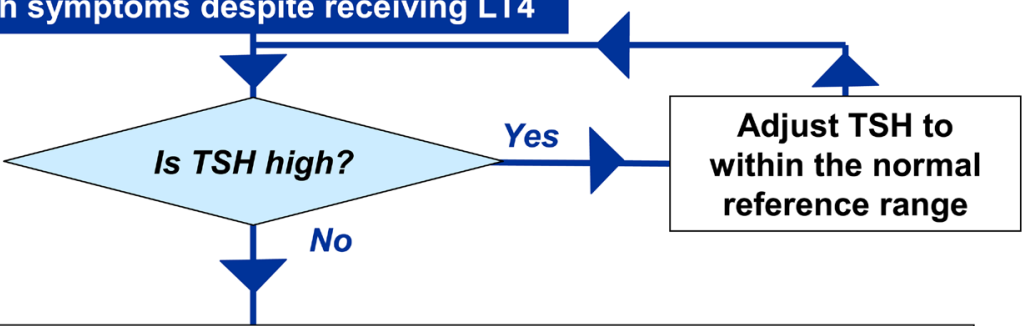

Check for:

- Other conditions or treatments that could cause the problem

- Sub-optimal adherence

- Possibility of malabsorption or altered LT4 metabolism

- Appropriate use of LT4 by the patient

Address issues and optimise LT4 dosage based on TSH

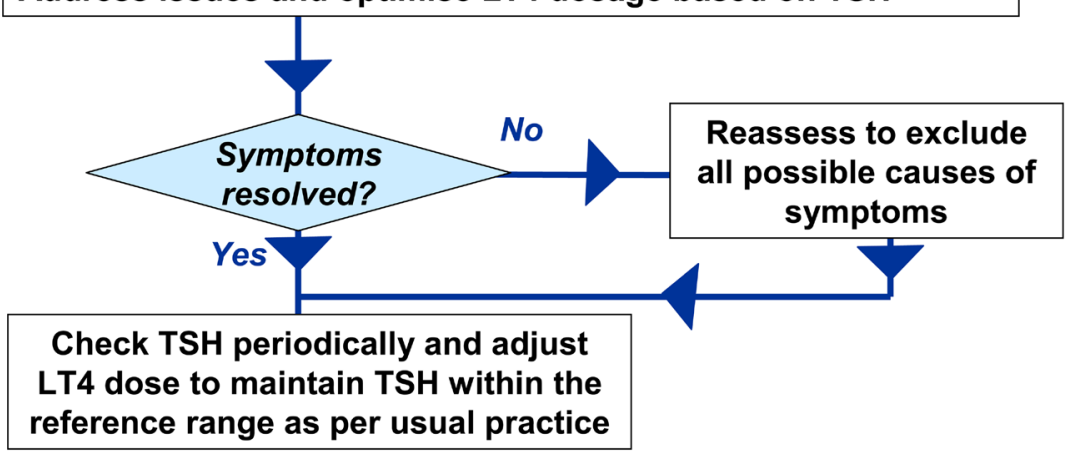

Figure 1

Overview of management of patients with hypothyroidism who continue to report symptoms of that condition despite receiving levothyroxine therapy. (c) 2020 The authors Published by Bioscientifica Ltd

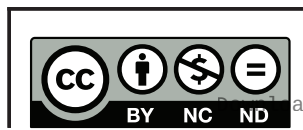

This work is licensed under a Creative Commons Attribution-NonCommercial-NoDerivatives 4.0 elmternationab dicense ifica.com at 04/26/2023 10:50:34AM 
Table 2 Pragmatic approach to managing a patient with continued symptoms of hypothyroidism despite apparently adequate levothyroxine therapy.

Take a thorough medical history

Careful initial examination to identify potential other causes for hypothyroid-like symptoms

Check the diagnosis of hypothyroidism and lab results

Ensure TSH is well controlled first

Check for patient factors and concomitant drug treatments that might have interfered with the TSH assay

Check for sub-optimal compliance

Is the patient taking all required doses?

Check for factors that could alter the metabolism of thyroid hormones

Potential for malabsorption of LT4

Some treatments affect thyroid hormone metabolism

Check how the patient uses LT4

Does the patient take LT4 in the fasting state at the start of the day, as per label?

Does the patient adjust the timing of other therapies that could interfere with LT4 absorption?

Is the patient storing their LT4 correctly?

Does the patient have the correct LT4 tablets, as per prescription?

See text for references

between the patient's symptoms and thyroid status (52). Figure 1 and Table 2 summarize a pragmatic approach to managing these patients, with individual steps described in more detail subsequently.

\section{Initial examination}

Initially, it is important to conduct a thorough examination to exclude causes of these symptoms that are not related to thyroid dysfunction, such as conditions producing chronic fatigue. Physicians need to be alert to the possibility that the 'hypothyroid-like' symptoms are not, in fact, related to underlying thyroid dysfunction. Most individuals diagnosed with hypothyroidism have an autoimmune etiology underlying the condition, and the presence of one autoimmune disorder suggests an increased risk of a range of other conditions associated with reduced quality of life $(53,54,55)$. For example, an observational study from the UK found a prevalence of rheumatoid arthritis of $4.2 \%$ among patients with Hashimoto's thyroiditis (53) (cf. $<1 \%$ in the general population (56)). The relative risks of other autoimmune conditions (pernicious anemia, systemic lupus erythematosus, Addison's disease, celiac disease, and vitiligo) were increased by more than tenfold in people with vs without Hashimoto's thyroiditis (53). Patients with hypothyroidism and new or persistent symptoms may therefore be screened for other comorbid autoimmune conditions.

\section{Is TSH adequately controlled?}

As many as one-third of patients with hypothyroidism may have an elevated TSH level, consistent with suboptimal replacement of LT4 therapy (57). Possible causes of this finding include underdosing with LT4, patient nonconcordance, aberrant assay results, and malabsorption of LT4: these are described briefly subsequently. Correcting the level of TSH to within its reference range may be sufficient for most patients $(1,2,3,58,59)$.

Variations of TSH levels within the euthyroid range have been reported to correlate with increased risk of a first adverse cardiovascular event (60), and with menopausal symptoms (61) or decreased bone mineral density/increased fracture risk (62) in perimenopausal or menopausal women. An increased risk of adverse cardiovascular outcomes and fractures has been observed in patients already receiving LT4 therapy who have TSH levels higher than the usual reference range of 0.4-4.0 $\mathrm{mIU} / \mathrm{L}$ (63). These studies suggest that minor variations on TSH could have important, long-term functional consequences. However, there is no evidence that varying the dose of LT4 treatment to alter TSH levels within the reference range is of benefit in the day-today management of people with hypothyroidism. Data from a case-control study suggested that LT4 therapy was effective in improving symptoms associated with hypothyroidism, but this was mainly associated with correcting aberrant TSH levels (64). Elsewhere, LT4treated hypothyroid patients with TSH within the normal range were randomized to higher, unchanged or lower LT4 doses for 6 months (serum TSH at study end ranged from 1.5-9.5 mIU/L) (65). Altering the LT4 dose was not associated with significant changes in questionnaire scores for mood, cognition or quality of life. A meta-analysis of 21 randomized trials did not support improvement in quality of life or thyroid-related symptoms associated with the treatment of subclinical hypothyroidism with LT4 vs placebo or no treatment (66). Finally, aiming for TSH levels in the lower half of the reference range $(<2$ $\mathrm{mIU} / \mathrm{L}$ ) did not improve symptoms or measures of wellbeing or quality of life compared with less intensive management of TSH in a randomized trial (67). This trial mitigates away from a policy of controlling TSH to within the lower half of the normal reference range, although further research will be needed to identify if there are specific subgroups of patients who could potentially benefit from such an approach.

In addition to the previously, increased TSH secretion may occur in obese patients or in the elderly

This work is licensed under a Creative Commons Attribution-NonCommercial-NoDerivatives 4.0 internationad bicense.ifica.com at 04/26/2023 10:50:34AM 
(where age-specific reference ranges are not used). Increased TSH secretion may also occur when the patient ingests certain therapies (e.g. lithium, amiodarone), foodstuffs (e.g. dietary soya) or toxins (e.g. endocrine disruptors) concomitantly with LT4 $(68,69,70)$. Dietary soya, as well as calcium, iron or iodide supplements may reduce the absorption of LT4 into the circulation $(68,69,70)$. The presence of rhesus factor (estimated prevalence $\leq 0.24 \%$ of the general population), macro-TSH (estimated prevalence $0.6-1.6 \%)$ and autoantibodies to thyroid hormones (estimated prevalence $1.8 \%$ ) may interfere directly with a TSH test, providing aberrant results (71). As many as $6 \%$ of patients may have heterophilic antibodies in their circulation (71), especially human anti-mouse antibody: these antibodies can recognize the animal-derived antibodies used in some immunoassays for TSH, leading to a falsely elevated TSH result $(72,73)$. Interference with a TSH test is a relatively uncommon reason for a mismatch between the measured TSH level and continuance of hypothyroid-like symptoms, but should be considered where other potential causes have been excluded.

\section{Is the patient taking levothyroxine as directed?}

Non-concordance to LT4 treatment is common and may increase over time (74). A database study from the USA showed that about two-fifths of patients were nonadherent to LT4 at 6 months, and about half of patients were non-adherent at 12 months (74). About one-third of patients were non-adherent to LT4 therapy in a survey in Turkey (75). In addition, the likelihood of sub-optimal adherence to LT4 appears to vary according to the preparation prescribed $(74,76)$. Sub-optimal adherence to LT4 therapy has important negative consequences for long-term outcomes: better adherence to LT4 therapy has been associated with reduced need for healthcare resources and enhanced long-term health trajectory in a large database analysis (77). A TSH test conducted after a period of supervised administration of LT4 can help to identify patients whose chronically elevated TSH is due to missed doses of LT4 (78).

\section{Is there altered absorption or metabolism of LT4?}

LT4 is absorbed via the intestine, and intestinal disorders may influence the absorption of LT4 and thus the dosage required to control the TSH level (79). For example, one study showed that people with ulcerative colitis and hypothyroidism required doses of LT4 that were $26 \%$ higher compared with those without ulcerative colitis (80). As with sub-optimal adherence described previously, longterm elevation of TSH due to malabsorption of LT4 has adverse clinical consequences (81). A switch to a different formulation of LT4 may help to resolve issues related to LT4 malabsorption (82), and a questionnaire-based tool is available to support the best choice of formulation (834). Alternatively, the use of a LT4 absorption test may help to differentiate cases of true malabsorption from patients with poor adherence to therapy (85). Liver cirrhosis also increases the dose requirement for LT4 $(86,87)$. Numerous medications alter the metabolism or excretion of thyroid hormones, and can influence circulating levels (88).

\section{Is the patient using LT4 correctly?}

Patients may need to be reminded to take their LT4 precisely as directed. The absorption of LT4 is also reduced by concomitant food intake, resulting in higher and more variable TSH levels, compared with administration in the fasting state (89). Dosing recommendations vary to some extent between regions. Levothyroxine should be taken 'at least half an hour before breakfast' (some levothyroxine products in Europe) (90) or 'preferably one-half to $1 \mathrm{~h}$ before breakfast' (USA) (91). Patients need to understand precisely how to take their LT4.

The European labels for LT4 products note that the absorption of LT4 is influenced by a range of treatments, including antacids, proton pump inhibitors, calcium salts, cimetidine, oral iron, and cholesterol absorbing resins (colestipol and cholestyramine), with a recommendation that the dosing of LT4 and these agents should be separated by at least $4 \mathrm{~h}$ (90). LT4 also has pharmacodynamic interactions with a number of other treatments that can increase or decrease their effects (92).

It is worth checking that the patient's LT4 tablets correspond to those prescribed, as dispensing errors are not unknown. In addition, check with the patient how they store their LT4 tablets (labeling typically recommends storing them away from light in their original packaging, and below a given temperature). Finally, if a patient is dissatisfied with their LT4 monotherapy, it is important to take some time to try to understand the nature and causes of their symptoms. A patient with distressing symptoms that they attribute to hypothyroidism (whether or not causally attributable to thyroid dysfunction) may turn for support to providers of 'complementary/ alternative medicine', whose advice and products may be inappropriate, ineffective, or harmful (93). Taking a

This work is licensed under a Creative Commons Attribution-NonCommercial-NoDerivatives 4.0 elnternationad dicense ifica. com at 04/26/2023 10:50:34AM 
holistic view and trying to ensure that the patient feels well will help to maintain trust and cooperation between the physician and patient, which will promote better concordance with treatment.

\section{Discussion and conclusions}

We have set out to provide a focused and pragmatic review for the practising physician faced with a patient with symptoms reminiscent of hypothyroidism despite optimization of LT4 according to current guidelines. Although this is not a formal systematic review, which is a limitation of our article, we used a priori criteria to guide our search strategy, which is a strength. The status of T3-LT4 combination therapy is perhaps the largest source of uncertainty in this area, with an apparent mismatch between persistent (especially observational) reports of psychological benefit and the largely neutral results of randomized trials and meta-analyses (reviewed previously). We have not explored this subject in depth, in contrast with earlier reviews, which have described this area in more detail $(31,39,42)$, as current guidelines advise clearly against this approach (if a trial period of treatment with a combination of T3 with LT4 is conducted for an individual patient, it is important to monitor carefully for signs of iatrogenic thyrotoxicosis (42)).

A substantial minority of patients with hypothyroidism continue to experience symptoms reminiscent of this condition, despite the application of levothyroxine therapy. It is important to exclude the presence of other conditions that may give rise to these symptoms. Chronically elevated TSH may be caused by underdosing of LT4, poor adherence to therapy, taking the treatment with food or drugs that interact with LT4, or intestinal malabsorption of LT4. Careful and systematic evaluation of the cause of the raised TSH level will then facilitate the achievement of an optimal LT4 regimen.

\section{Declaration of interest}

S R received speaker fees from Merck plc, Abbott Pharmaceuticals India Ltd and Berlin Chemie plc, makers of levothyroxine. S M is an employee of Merck Serono Middle East FZ-LLC. M L received speaker fees from Merck, Sanofi, Bayer Healthcare and Eisai. A medical writer (Dr Mike Gwilt, GT Communications, funded by Merck Serono Middle East FZ-LLC) provided editorial assistance.

\section{Funding}

This article did not receive any specific grant from any funding agency in the public, commercial or not-for-profit sector, other than medical writing services, as described previously. Authors did not receive payment for contributing to the development of this article.

\section{Author contribution statement}

All authors provided material for inclusion in the article, contributed to the development of the article, and approved its submission for publication. $\mathrm{S} \mathrm{R}$ led the process of writing and reviewing the manuscript during its development. The manuscript underwent an obligatory internal review by S M's employer, which was conducted for regulatory purposes and to ensure appropriate and accurate reporting of published literature: this review did not change the content of the article, or the interpretation of the clinical evidence cited within it.

\section{References}

1 Okosieme O, Gilbert J, Abraham P, Boelaert K, Dayan C, Gurnell M, Leese G, McCabe C, Perros P, Smith V, et al. Management of primary hypothyroidism: statement by the British Thyroid Association Executive Committee. Clinical Endocrinology 201684 799-808. (https://doi.org/10.1111/cen.12824)

2 National Institute for Health and Care Excellence. Clinical Knowledge Summaries. Hypothyroidism. Revised June 2018. London, UK: NICE, 2018. (available at: https://cks.nice.org.uk/ hypothyroidism)

3 Jonklaas J, Bianco AC, Bauer AJ, Burman KD, Cappola AR, Celi FS, Cooper DS, Kim BW, Peeters RP, Rosenthal MS, et al. Guidelines for the treatment of hypothyroidism: prepared by the American Thyroid Association Task Force on thyroid hormone replacement. Thyroid 201424 1670-1751. (https://doi.org/10.1089/ thy.2014.0028)

4 Vanderpump MP \&Tunbridge WM. Epidemiology and prevention of clinical and subclinical hypothyroidism. Thyroid 200212 839-847. (https://doi.org/10.1089/105072502761016458)

5 Unnikrishnan AG, Kalra S, Sahay RK, Bantwal G, John M \& Tewari N. Prevalence of hypothyroidism in adults: an epidemiological study in eight cities of India. Indian Journal of Endocrinology and Metabolism 201317 647-652. (https://doi.org/10.4103/2230-8210.113755)

6 Taylor PN, Iqbal A, Minassian C, Sayers A, Draman MS, Greenwood R, Hamilton W, Okosieme O, Panicker V, Thomas SL, et al. Falling threshold for treatment of borderline elevated thyrotropin levels-balancing benefits and risks: evidence from a large community-based study. JAMA Internal Medicine 2014174 32-39. (https://doi.org/10.1001/jamainternmed.2013.11312)

7 Medici BB, Nygaard B, la Cour JL, Grand MK, Siersma V, Nicolaisdottir DR, Lind B, Olivarius NF \& Andersen CL. Changes in prescription routines for treating hypothyroidism between 2001 and 2015: an observational study of 929,684 primary care patients in Copenhagen. Thyroid 201929 910-919. (https://doi.org/10.1089/ thy.2018.0539)

8 Rodriguez-Gutierrez R, Maraka S, Ospina NS, Montori VM \& Brito JP. Levothyroxine overuse: time for an about face? Lancet: Diabetes and Endocrinology 20175 246-248. (https://doi.org/10.1016/S22138587(16)30276-5)

9 Peterson SJ, Cappola AR, Castro MR, Dayan CM, Farwell AP, Hennessey JV, Kopp PA, Ross DS, Samuels MH, Sawka AM, et al. An online survey of hypothyroid patients demonstrates prominent dissatisfaction. Thyroid 201828 707-721. (https://doi.org/10.1089/ thy.2017.0681)

10 Saravanan P, Chau WF, Roberts N, Vedhara K, Greenwood R \& Dayan CM. Psychological well-being in patients on 'adequate' doses of l-thyroxine: results of a large, controlled community-based questionnaire study. Clinical Endocrinology 200257 577-585. (https:// doi.org/10.1046/j.1365-2265.2002.01654.x) https://ec.bioscientifica.com

https://doi.org/10.1530/EC-20-0205 (c) 2020 The authors Published by Bioscientifica Ltd
This work is licensed under a Creative Commons Attribution-NonCommercial-NoDerivatives 4.0 elnternational License.ifica com at $04 / 26 / 2023$ 10:50:34AM 
11 Saravanan P, Visser TJ \& Dayan CM. Psychological well-being correlates with free thyroxine but not free 3,5,3'-triiodothyronine levels in patients on thyroid hormone replacement. Journal of Clinical Endocrinology and Metabolism 200691 3389-3393. (https://doi. org/10.1210/jc.2006-0414)

12 Ernst FR, Barr P, Elmor R, Sandulli W, Thevathasan L, Sterman AB, Goldenberg J \& Vora K. The economic impact of levothyroxine dose adjustments: the CONTROL HE Study. Clinical Drug Investigation 201737 71-83. (https://doi.org/10.1007/s40261-016-0462-3)

13 Canaris GJ, Manowitz NR, Mayor G \& Ridgway EC. The Colorado thyroid disease prevalence study. Archives of Internal Medicine 2000 160 526-534. (https://doi.org/10.1001/archinte.160.4.526)

14 Pollock MA, Sturrock A, Marshall K, Davidson KM, Kelly CJ, McMahon AD \& McLaren EH. Thyroxine treatment in patients with symptoms of hypothyroidism but thyroid function tests within the reference range: randomised double blind placebo controlled crossover trial. BMJ 2001323 891-895. (https://doi.org/10.1136/ bmj.323.7318.891)

15 National Health Service. Underactive thyroid (hypothyroidism) Symptoms. London, UK: NHS, 2018. (available at: https://www.nhs. uk/conditions/underactive-thyroid-hypothyroidism/symptoms/)

16 Centanni M, Benvenga S \& Sachmechi I. Diagnosis and management of treatment-refractory hypothyroidism: an expert consensus report. Journal of Endocrinological Investigation 201740 1289-1301. (https:// doi.org/10.1007/s40618-017-0706-y)

17 Canaris GJ, Steiner JF \& Ridgway EC. Do traditional symptoms of hypothyroidism correlate with biochemical disease? Journal of General Internal Medicine 199712 544-550. (https://doi.org/10.1046/ j.1525-1497.1997.07109.x)

18 Carlé A, Pedersen IB, Knudsen N, Perrild H, Ovesen L \& Laurberg P. Hypothyroid symptoms and the likelihood of overt thyroid failure: a population-based case-control study. European Journal of Endocrinology 2014171 593-602. (https://doi.org/10.1530/EJE-14-0481)

19 British Thyroid Foundation. Psychological symptoms and thyroid disorders. Harrogate, UK: BTF, 2018. (available at: http://www.btfthyroid.org/information/leaflets/37-psychological-symptoms-guide)

20 Braverman LE, Vagenakis A, Downs P, Foster AE, Sterling K \& Ingbar SH. Effects of replacement doses of sodium L-thyroxine on the peripheral metabolism of thyroxine and triiodothyronine in man. Journal of Clinical Investigation 197352 1010-1017. (https://doi. org/10.1172/JCI107265)

21 Pilo A, Iervasi G, Vitek F, Ferdeghini M, Cazzuola F \& Bianchi R. Thyroidal and peripheral production of 3,5,3'-triiodothyronine in humans by multicompartmental analysis. American Journal of Physiology 1990258 E715-E726. (https://doi.org/10.1152/ ajpendo.1990.258.4.E715)

22 Jonklaas J, Davidson B, Bhagat S \& Soldin SJ. Triiodothyronine levels in athyreotic individuals during levothyroxine therapy. JAMA 2008 299 769-777. (https://doi.org/10.1001/jama.299.7.769)

23 Peterson SJ, McAninch EA \& Bianco AC. Is a normal TSH synonymous with 'euthyroidism' in levothyroxine monotherapy? Journal of Clinical Endocrinology and Metabolism $20161014964-4973$. (https://doi.org/10.1210/jc.2016-2660)

24 Gullo D, Latina A, Frasca F, Le Moli R, Pellegriti G \& Vigneri R. Levothyroxine monotherapy cannot guarantee euthyroidism in all athyreotic patients. PLOS ONE 20116 e22552. (https://doi. org/10.1371/journal.pone.0022552)

25 Ito M, Miyauchi A, Morita S, Kudo T, Nishihara E, Kihara M, Takamura Y, Ito Y, Kobayashi K, Miya A, et al. TSH-suppressive doses of levothyroxine are required to achieve preoperative native serum triiodothyronine levels in patients who have undergone total thyroidectomy. European Journal of Endocrinology 2012167 373-378. (https://doi.org/10.1530/EJE-11-1029)

26 Escobar-Morreale HF, Obregón MJ, Escobar del Rey F \& Morreale de Escobar G. Replacement therapy for hypothyroidism with thyroxine alone does not ensure euthyroidism in all tissues, as studied in thyroidectomized rats. Journal of Clinical Investigation 199596 2828-2838. (https://doi.org/10.1172/JCI118353)

27 Larsen PR \& Zavacki AM. The role of the iodothyronine deiodinases in the physiology and pathophysiology of thyroid hormone action. European Thyroid Journal 20121 232-242. (https://doi. org/10.1159/000343922)

28 Bianco AC. Cracking the code for thyroid hormone signaling. Transactions of the American Clinical and Climatological Association 2013124 26-35.

29 Canani LH, Capp C, Dora JM, Meyer EL, Wagner MS, Harney JW, Larsen PR, Gross JL, Bianco AC \& Maia AL. The type 2 deiodinase A/G (Thr92Ala) polymorphism is associated with decreased enzyme velocity and increased insulin resistance in patients with type 2 diabetes mellitus. Journal of Clinical Endocrinology and Metabolism 200590 3472-3478. (https://doi.org/10.1210/jc.2004-1977)

30 Peeters RP \& Visser TJ. Metabolism of thyroid hormone. Endotext. South Dartmouth, MA, USA: MDText Inc, 2017. (available at: https:// www.ncbi.nlm.nih.gov/books/NBK285545)

31 Jonklaas J. Persistent hypothyroid symptoms in a patient with a normal thyroid stimulating hormone level. Current Opinion in Endocrinology, Diabetes, and Obesity 201724 356-363. (https://doi. org/10.1097/MED.0000000000000355)

32 Bunevicius R, Kazanavicius G, Zalinkevicius R \& Prange AJ Jr. Effects of thyroxine as compared with thyroxine plus triiodothyronine in patients with hypothyroidism. New England Journal of Medicine 1999 340 424-429. (https://doi.org/10.1056/NEJM199902113400603)

33 Nygaard B, Jensen EW, Kvetny J, Jarløv A \& Faber J. Effect of combination therapy with thyroxine (T4) and 3,5,3'-triiodothyronine versus T4 monotherapy in patients with hypothyroidism, a double-blind, randomised cross-over study. European Journal of Endocrinology 2009161 895-902. (https://doi. org/10.1530/EJE-09-0542)

34 Tariq A, Wert Y, Cheriyath P \& Joshi R. Effects of long-term combination LT4 and LT3 therapy for improving hypothyroidism and overall quality of life. Southern Medical Journal 2018111 363-369. (https://doi.org/10.14423/SMJ.0000000000000823)

35 Grozinsky-Glasberg S, Fraser A, Nahshoni E, Weizman A \& Leibovici L. Thyroxine-triiodothyronine combination therapy versus thyroxine monotherapy for clinical hypothyroidism: meta-analysis of randomized controlled trials. Journal of Clinical Endocrinology and Metabolism 200691 2592-2599. (https://doi.org/10.1210/jc.20060448)

36 Medici BB, la Cour JL, Michaelsson LF, Faber JO \& Nygaard B. Neither baseline nor changes in serum triiodothyronine during levothyroxine/liothyronine combination therapy predict a positive response to this treatment modality in hypothyroid patients with persistent symptoms. European Thyroid Journal 20176 89-93. (https:// doi.org/10.1159/000454878)

37 Michaelsson LF, la Cour JL, Medici BB, Watt T, Faber J \& Nygaard B. Levothyroxine/liothyronine combination therapy and quality of life: is it all about weight loss? European Thyroid Journal 20187 243-250. (https://doi.org/10.1159/000490383)

38 Fischman A \& Domínguez JM. Combined therapy with levothyroxine and liothyronine for hypothyroidism. Terapia combinada de levotiroxina y liotironina para hipotiroidismo. Medwave 201818 e7376. (https://doi.org/10.5867/medwave.2018.08.7375)

39 Dayan C \& Panicker V. Management of hypothyroidism with combination thyroxine (T4) and triiodothyronine (T3) hormone replacement in clinical practice: a review of suggested guidance. Thyroid Research 201811 1. (https://doi.org/10.1186/s13044-0180045-x)

40 Akirov A, Fazelzad R, Ezzat S, Thabane L \& Sawka AM. A systematic review and meta-analysis of patient preferences for combination thyroid hormone treatment for hypothyroidism. Frontiers in Endocrinology 201910 477. (https://doi.org/10.3389/ fendo.2019.00477) 
41 Leese GP, Soto-Pedre E \& Donnelly LA. Liothyronine use in a 17 year observational population-based study - the tears study. Clinical Endocrinology 201685 918-925. (https://doi.org/10.1111/cen.13052)

42 Wiersinga WM, Duntas L, Fadeyev V, Nygaard B \& Vanderpump MP. 2012 ETA guidelines: the use of L-T4+L-T3 in the treatment of hypothyroidism. European Thyroid Journal 20121 55-71. (https://doi. org/10.1159/000339444)

43 Michaelsson LF, Medici BB, la Cour JL, Selmer C, Røder M, Perrild H, Knudsen N, Faber J \& Nygaard B. Treating hypothyroidism with thyroxine/triiodothyronine combination therapy in Denmark: following guidelines or following trends? European Thyroid Journal 20154 174-180. (https://doi.org/10.1159/000437262)

44 Bianco AC \& Kim BS. Pathophysiological relevance of deiodinase polymorphism. Current Opinion in Endocrinology, Diabetes, and Obesity 201825 341-346. (https://doi.org/10.1097/ MED.0000000000000428)

45 Jo S, Fonseca TL, Bocco BMLC, Fernandes GW, McAninch EA, Bolin AP, Da Conceição RR, Werneck-de-Castro JP, Ignacio DL, Egri P, et al. Type 2 deiodinase polymorphism causes ER stress and hypothyroidism in the brain. Journal of Clinical Investigation 2019 129 230-245. (https://doi.org/10.1172/JCI123176)

46 Panicker V, Saravanan P, Vaidya B, Evans J, Hattersley AT, Frayling TM $\&$ Dayan CM. Common variation in the $\mathrm{DIO}_{2}$ gene predicts baseline psychological well-being and response to combination thyroxine plus triiodothyronine therapy in hypothyroid patients. Journal of Clinical Endocrinology and Metabolism 200994 1623-1629. (https:// doi.org/10.1210/jc.2008-1301)

47 Carlé A, Faber J, Steffensen R, Laurberg P \& Nygaard B. Hypothyroid patients encoding combined MCT10 and $\mathrm{DIO}_{2}$ gene polymorphisms may prefer L-T3 + L-T4 combination treatment - data using a blind, randomized, clinical study. European Thyroid Journal 20176 143-151. (https://doi.org/10.1159/000469709)

48 Heemstra KA, Hoftijzer HC, van der Deure WM, Peeters RP, Fliers E, Appelhof BC, Wiersinga WM, Corssmit EP, Visser TJ \& Smit JW. Thr92Ala polymorphism in the type 2 deiodinase is not associated with T4 dose in athyroid patients or patients with Hashimoto thyroiditis. Clinical Endocrinology 200971 279-283. (https://doi. org/10.1111/j.1365-2265.2008.03474.x)

49 Appelhof BC, Peeters RP, Wiersinga WM, Visser TJ, Wekking EM, Huyser J, Schene AH, Tijssen JG, Hoogendijk WJ \& Fliers E. Polymorphisms in type 2 deiodinase are not associated with wellbeing, neurocognitive functioning, and preference for combined thyroxine/3,5,3'-triiodothyronine therapy. Journal of Clinical Endocrinology and Metabolism 200590 6296-6299. (https://doi. org/10.1210/jc.2005-0451)

50 Stefan M \& Faustino LC. Genetics of thyroid-stimulating hormone receptor-relevance for autoimmune thyroid disease. Frontiers in Endocrinology 20178 57. (https://doi.org/10.3389/fendo.2017.00057)

51 Cortés JMR \& Zerón HM. Genetics of thyroid disorders. Folia Medica 201961 172-179. (https://doi.org/10.2478/folmed-2018-0078)

52 Huang CJ \& Jap TS. A systematic review of genetic studies of thyroid disorders in Taiwan. Journal of the Chinese Medical Association 201578 145-153. (https://doi.org/10.1016/j.jcma.2014.09.010)

53 Boelaert K, Newby PR, Simmonds MJ, Holder RL, Carr-Smith JD, Heward JM, Manji N, Allahabadia A, Armitage M, Chatterjee KV, et al. Prevalence and relative risk of other autoimmune diseases in subjects with autoimmune thyroid disease. American Journal of Medicine 2010 123 183.e1-183.e9. (https://doi.org/10.1016/j.amjmed.2009.06.030)

54 Somers EC, Thomas SL, Smeeth L \& Hall AJ. Are individuals with an autoimmune disease at higher risk of a second autoimmune disorder? American Journal of Epidemiology 2009169 749-755. (https://doi.org/10.1093/aje/kwn408)

55 Cojocaru M, Cojocaru IM \& Silosi I. Multiple autoimmune syndrome. Maedica 20105 132-134.

56 Symmons D, Turner G, Webb R, Asten P, Barrett E, Lunt M, Scott D $\&$ Silman A. The prevalence of rheumatoid arthritis in the United
Kingdom: new estimates for a new century. Rheumatology 200241 793-800. (https://doi.org/10.1093/rheumatology/41.7.793)

57 McNally LJ, Ofiaeli CI \& Oyibo SO. Treatment-refractory hypothyroidism. BMJ 2019364 1579. (https://doi.org/10.1136/bmj. 1579)

58 Razvi S \& Hostalek U. Therapeutic challenges in the application of serum thyroid stimulating hormone testing in the management of patients with hypothyroidism on replacement thyroid hormone therapy: a review. Current Medical Research and Opinion 201935 1215-1220. (https://doi.org/10.1080/03007995.2019.1570769)

59 Jonklaas J \& Razvi S. Reference intervals in the diagnosis of thyroid dysfunction: treating patients not numbers. Lancet: Diabetes and Endocrinology 20197 473-483. (https://doi.org/10.1016/S22138587(18)30371-1)

60 Åsvold BO, Vatten LJ, Bjøro T, Bauer DC, Bremner A, Cappola AR, Ceresini G, den Elzen WP, Ferrucci L, Franco OH, et al. Thyroid function within the normal range and risk of coronary heart disease: an individual participant data analysis of 14 cohorts. JAMA Internal Medicine 2015175 1037-1047. (https://doi.org/10.1001/ jamainternmed.2015.0930)

61 Slopien R, Owecki M, Slopien A, Bala G \& Meczekalski B. Climacteric symptoms are related to thyroid status in euthyroid menopausal women. Journal of Endocrinological Investigation 202043 75-80. (https://doi.org/10.1007/s40618-019-01078-7)

62 Murphy E, Glüer CC, Reid DM, Felsenberg D, Roux C, Eastell R \& Williams GR. Thyroid function within the upper normal range is associated with reduced bone mineral density and an increased risk of nonvertebral fractures in healthy euthyroid postmenopausal women. Journal of Clinical Endocrinology and Metabolism 201095 3173-3181. (https://doi.org/10.1210/jc.2009-2630)

63 Flynn RW, Bonellie SR, Jung RT, MacDonald TM, Morris AD \& Leese GP. Serum thyroid-stimulating hormone concentration and morbidity from cardiovascular disease and fractures in patients on long-term thyroxine therapy. Journal of Clinical Endocrinology and Metabolism 201095 186-193. (https://doi.org/10.1210/jc.20091625)

64 Singh R, Tandon A, Gupta SK \& Saroja K. Optimal levothyroxine replacement adequately improves symptoms of hypothyroidism; residual symptoms need further evaluation for other than hypothyroidism causation. Indian Journal of Endocrinology and Metabolism 201721 830-835. (https://doi.org/10.4103/ijem. IJEM_165_17)

65 Samuels MH, Kolobova I, Niederhausen M, Janowsky JS \& Schuff KG. Effects of altering levothyroxine (L-T4) doses on quality of life, mood, and cognition in L-T4 treated subjects. Journal of Clinical Endocrinology and Metabolism 2018103 1997-2008. (https://doi. org/10.1210/jc.2017-02668)

66 Feller M, Snel M, Moutzouri E, Bauer DC, de Montmollin M, Aujesky D, Ford I, Gussekloo J, Kearney PM, Mooijaart S, et al. Association of thyroid hormone therapy with quality of life and thyroid-related symptoms in patients with subclinical hypothyroidism: a systematic review and meta-analysis. JAMA 2018 320 1349-1359. (https://doi.org/10.1001/jama.2018.13770)

67 Walsh JP, Ward LC, Burke V, Bhagat CI, Shiels L, Henley D, Gillett MJ, Gilbert R, Tanner M \& Stuckey BG. Small changes in thyroxine dosage do not produce measurable changes in hypothyroid symptoms, well-being, or quality of life: results of a double-blind, randomized clinical trial. Journal of Clinical Endocrinology and Metabolism 200691 2624-2630. (https://doi.org/10.1210/jc.2006-0099)

68 Razvi S, Bhana S \& Mrabeti S. Challenges in interpreting thyroid stimulating hormone results in the diagnosis of thyroid dysfunction. Journal of Thyroid Research 20192019 1-8. (https://doi. org/10.1155/2019/4106816) 4106816.

69 Burch HB. Drug effects on the thyroid. New England Journal of Medicine $20193 \mathbf{8 1}$ 749-761. (https://doi.org/10.1056/ NEJMra1901214) 
70 Lupoli R, Di Minno A, Tortora A, Ambrosino P, Lupoli GA \& Di Minno MN. Effects of treatment with metformin on TSH levels: a meta-analysis of literature studies. Journal of Clinical Endocrinology and Metabolism 201499 E143-E148. (https://doi.org/10.1210/ jc.2013-2965)

71 Favresse J, Burlacu MC, Maiter D \& Gruson D. Interferences with thyroid function immunoassays: clinical implications and detection algorithm. Endocrine Reviews 201839 830-850. (https://doi. org/10.1210/er.2018-00119)

72 Faix JD, Thienpoint LM \& American Association of Clinical Chemists. Thyroid-stimulating hormone. Why efforts to harmonize testing are critical to patient care. In Clinical Laboratory News. Washington, DC, USA: AACC, 2013. (available at: https://www.aacc. org/publications/cln/articles/2013/may/tsh-harmonization)

73 Després N \& Grant AM. Antibody interference in thyroid assays: a potential for clinical misinformation. Clinical Chemistry 199844 440-454. (https://doi.org/10.1093/clinchem/44.3.440)

74 Hepp Z, Wyne K, Manthena SR, Wang S \& Gossain V. Adherence to thyroid hormone replacement therapy: a retrospective, claims database analysis. Current Medical Research and Opinion 201834 1673-1678. (https://doi.org/10.1080/03007995.2018.1486293)

75 Yavuz DG, Keskin L, Atmaca A, Dikbas O, Hekimsoy Z, Sahin I, Yalin S, Yilmaz M, Uygur M, Yazici D, et al. Adherence of levothyroxine treatment in primary hypothyroid patients in Turkey: a multicenter study. Endocrine Abstracts 201435 P1048. (https://doi. org/10.1530/endoabs.35.P1048)

76 Cappelli C, Castello R, Marini F, Paoletta A, Marchetti M, Saullo M, Cristiano A, Pirola I, Gandossi E, Ferlin A, et al. Adherence to levothyroxine treatment among patients with hypothyroidism: a Northeastern Italian survey. Frontiers in Endocrinology 20189699. (https://doi.org/10.3389/fendo.2018.00699)

77 Hepp Z, Lage MJ, Espaillat R \& Gossain VV. The association between adherence to levothyroxine and economic and clinical outcomes in patients with hypothyroidism in the US. Journal of Medical Economics 201821 912-919. (https://doi.org/10.1080/13696998.2018.1484749)

78 Rdzak GM, Whitman LM \& Inzucchi SE. Levothyroxine pseudomalabsorption: testing and treatment in the outpatient setting. Therapeutic Advances in Endocrinology and Metabolism 20189 217-222. (https://doi.org/10.1177/2042018818771433)

79 Hays MT. Localization of human thyroxine absorption. Thyroid 1991 1 241-248. (https://doi.org/10.1089/thy.1991.1.241)

80 Virili C, Stramazzo I, Santaguida MG, Bruno G, Brusca N, Capriello S, Cellini M, Severi C, Gargano L \& Centanni M. Ulcerative colitis as a novel cause of increased need for levothyroxine. Frontiers in Endocrinology 201910 233. (https://doi.org/10.3389/ fendo.2019.00233)

81 Benvenga S, Pantano R, Saraceno G, Lipari L, Alibrando A, Inferrera S, Pantano G, Simone G, Tamà S, Scoglio R, et al. A minimum of two years of undertreated primary hypothyroidism, as a result of drug-induced malabsorption of l-thyroxine, may have metabolic and cardiovascular consequences. Journal of Clinical and Translational Endocrinology 201916 100189. (https://doi org/10.1016/j.jcte.2019.100189)

82 Laurent I, Tang S, Astère M, Wang KR, Deng S, Xiao L \& Li QF. Liquid L-thyroxine versus tablet L-thyroxine in patients on L-thyroxine replacement or suppressive therapy: a meta-analysis. Endocrine 2018 61 28-35. (https://doi.org/10.1007/s12020-018-1574-8)

83 Koulouri O, Moran C, Halsall D, Chatterjee K \& Gurnell M. Pitfalls in the measurement and interpretation of thyroid function tests. Best Practice and Research: Clinical Endocrinology and Metabolism 201327 745-762. (https://doi.org/10.1016/j.beem.2013.10.003)

84 Yildirim Simsir I, Soyaltin UE \& Ozgen AG. Levothyroxine absorption test results in patients with TSH elevation resistant to treatment. Endocrine 201964 118-121. (https://doi.org/10.1007/ s12020-019-01889-x)

85 Horn JR \& Hansten PD. Drugs affecting levothyroxine absorption. In Pharmacy Times. Cranbury, NJ, USA: Pharmacy Times, 2016. (available at: https:/www.pharmacytimes.com/publications/ issue/2016/january2016/drugs-affecting-levothyroxineabsorption)

86 Benvenga S, Capodicasa G, Perelli S, Ferrari SM, Fallahi P \& Antonelli A. Increased requirement of replacement doses of levothyroxine caused by liver cirrhosis. Frontiers in Endocrinology 20189 150. (https://doi.org/10.3389/fendo.2018.00150)

87 Colucci P, Yue CS, Ducharme M \& Benvenga S. A review of the pharmacokinetics of levothyroxine for the treatment of hypothyroidism. European Endocrinology 20139 40-47. (https://doi. org/10.17925/EE.2013.09.01.40)

88 Bach-Huynh TG, Nayak B, Loh J, Soldin S \& Jonklaas J. Timing of levothyroxine administration affects serum thyrotropin concentration. Journal of Clinical Endocrinology and Metabolism 2009 94 3905-3912. (https://doi.org/10.1210/jc.2009-0860)

89 Heads of Medicines Agencies.Levothyroxine sodium 25 mg tablets. European Summary of Product Characteristics. Amsterdam, Netherlands, HMA, 2020. (available at: https://mri.cts-mrp.eu/ Human/Downloads/NL_H_2700_004_FinalSPC.pdf)

90 Abbott. Synthroid - Levothyroxine sodium tablet. Prescribing Information. North Chicago, IL, USA: Abbott Laboratories, 2008. (available at: https://www.accessdata.fda.gov/drugsatfda_docs/ label/2008/021402s017lbl.pdf)

91 Trifirò G, Parrino F, Sultana J, Giorgianni F, Ferrajolo C, Bianchini E, Medea G, Benvenga S, Cricelli I, Cricelli C, et al. Drug interactions with levothyroxine therapy in patients with hypothyroidism: observational study in general practice. Clinical Drug Investigation 201535 187-195. (https://doi.org/10.1007/s40261-015-0271-0)

92 American Thyroid Association. Complementary and alternative medicine in thyroid disease (CAM). Falls Church, VA, USA: ATA, 2020. (available at: https://www.thyroid.org/thyroid-disease-cam/)

Received in final form 27 July 2020

Accepted 5 October 2020

Accepted Manuscript published online 6 October 2020 https://ec.bioscientifica.com https://doi.org/10.1530/EC-20-0205 (c) 2020 The authors Published by Bioscientifica Ltd
This work is licensed under a Creative Commons Attribution-NonCommercial-NoDerivatives 4.0 elnternationad dicense ifica . com at 04/26/2023 10:50:34AM 